\title{
Rehberli Araş̧tırma Sorgulama Öğretim Yönteminin 7. Sınıf Öğrencilerinin FeTeMM Tutumları Üzerindeki Etkisi*
}

\author{
The Effect of Guided Research Inquiry Teaching Method on $7^{\text {th }}$ Grade Students' \\ STEM Attitudes
}

\author{
Uzm. Öğretmen Müge SAĞDIÇ ${ }^{(D)}$, Doç. Dr. Hasan BAKIRCI ${ }^{(D)}$
}

\begin{abstract}
$\ddot{\mathbf{O} z}$
Bu çalışmanın amacı, rehberli araştırma sorgulama öğretim yöntemine dayalı fen öğretiminin yedinci sınıf öğrencilerinin Fen-Teknoloji-Mühendislik-Matematik (FeTeMM) tutumlarına etkisini araştırmaktır. Çalışmada, yarı deneysel yöntem kullanılmıştır. Çalışma grubu, 2017-2018 eğitim-öğretim yılının güz döneminde Van ilinin Başkale ilçe merkezindeki bir ortaokulda 45'i deney (23 kız, 22 erkek) ve 40'1 kontrol grubunda (17 kız, 23 erkek) olmak üzere toplam 85 öğrenciden oluşmaktadır. Veri toplama araçları olarak; FeTeMM Tutum Ölçeği kullanılmıştır. Çalışmada elde edilen veriler, Wilcoxon İşaretli Sıralar Testi ve Mann Whitney U-testi kullanılarak analiz edilmiştir. Çalışmanın sonunda, deney grubunda uygulanan rehberli araştırma sorgulama öğretim yönteminin ve kontrol grubunda uygulanan 5E öğrenme modelinin yedinci sınıf öğrencilerinin FeTeMM tutumları üzerinde etkili olduğu bulunmuştur. Deney ve kontrol grubunda yapılan öğretim kıyaslandığında; deney grubunda yapılan öğretimin, ortaokul yedinci sınıf öğrencilerinin FeTeMM tutumları üzerinde daha etkili olduğu sonucuna varılmıştır. Ayrıca rehberli araştırma sorgulama öğretim yöntemine dayalı fen öğretimi, FeTeMM Tutum Ölçeği’nde yer alan özellikle fen ve 21. yüzyıl becerileri üzerinde daha etkili olduğu tespit edilmiştir. Çalışmadan elde edilen sonuçlara bağlı olarak, rehberli sorgulama öğretim modelinin ortaokul öğrencilerinin FeTeMM tutumları üzerinde etkisinin daha net görülebilmesi için Fen Bilimleri dersinin farklı ünitelerinde kullanılması önerilmektedir.
\end{abstract}

Anahtar Kelimeler: Fen eğitimi, rehberli araştırma sorgulama öğretim yöntemi, FeTeMM tutumu

Makale Türü: Araştırma

\begin{abstract}
This study aims to investigate the effect of science education based on a guided inquiry teaching model on Science-Technology-Engineering-Mathematics (STEM) attitudes of $7^{\text {th }}$-grade students. The research employs quasi-experimental method. The participants of the research are 85 students studying in a secondary school during the 2017-2018 academic year in Van. The participants were divided into two groups. The experiment group had 45 students ( 23 girls, 22 boys) and the control group had 40 students (17 girls, 23 boys). The data collection tool is the STEM Attitude Scale. The data in the study were analyzed using the Wilcoxon Signed Ranks Test and the Mann Whitney U-test. At the end of the study, the guided research inquiry teaching method applied in the experimental group and the 5E learning model applied in the control group were found to be effective on STEM attitudes of $7^{\text {th }}$ grade students. When science teaching methods used for the experimental and control groups are compared, it was concluded that the teaching in the experimental group was more effective on STEM attitudes of $7^{\text {th }}$-grade students. In addition, science teaching based on guided research inquiry teaching method was found to be more effective on the $21^{\text {st }}$ century skills included in the STEM Attitude Scale. Drawing on the findings, it is recommended to use the guided inquiry model in different units of the Science course in order to see its effect on secondary students' STEM attitudes more clearly.
\end{abstract}

\footnotetext{
*Bu çalıșma, birinci yazarın 2018 yılında tamamlanan yüksek lisans tezinden üretilmiștir. ${ }^{1}$ Millî Eğitim Bakanlı̆̆

${ }^{2}$ Van Yüzüncü Yıl Üniversitesi, Eğitim Fakültesi, hasanbakirci09@gmail.com.
}

Atıf için (to cite): Sağdıç. M. ve Bakırcı, H. (2020). Rehberli araştırma sorgulama öğretim yönteminin 7. sınıf öğrencilerinin FeTeMM tutumları üzerindeki etkisi. Afyon Kocatepe Üniversitesi Sosyal Bilimler Dergisi, 22(2), 363-376. 
Keywords: Science education, guided research inquiry teaching method, STEM attitude

Paper Type: Research

\section{Giriş}

Fen öğretimi, 2005 yılından itibaren yapılandırmacı öğrenme kuramını temel almıştır. Bu öğrenme kuramında; araştıran, sorgulayan, eleştirel ve yaratıcı düşünme becerilerine sahip bireylerin yetiştirilmesi amaçlanmıştır (Carlson, 1999). Bu amaçlar doğrultusunda, 21. yüzyıl becerilerine sahip bireylerin yetiştirilmesi ihtiyacı ortaya çıkmıştır. Bu durum, fen öğrenmeöğretme süreçlerinin yeniden yapılandırılması gereksinimini ortaya çıkarmıştır. Böylece birçok ülke; problem çözebilen, sorumluluk sahibi olan, karar verme becerileri gelişmiş, girişimci ve yenilikçi düşünebilen bireyler yetiştirmeye olanak sağlayacak bir eğitim-öğretim modeli arayışına yönelmiştir (Milli Eğitim Bakanlığı [MEB], 2017). Bu arayışların temelinde, öğrencilerin fen ögretimindeki başarılarını ve fen dersine karşı olan isteklerini artırmak hedeflenmiştir. Bu açıdan bakıldığında, yapılandırmacı öğrenme kuramında, araştırma sorgulamaya dayalı öğretimin önemi ortaya çıkmaktadır. Çünkü bu öğretimde, bilgilerin öğrenilmesinden çok, öğrenmeye karşı olumlu tutum geliştirilmesi ve öğrenme becerilerinin kazandırılması amaçlanmıştır (Artun ve Özsevgeç, 2014; Sarığlan, Can ve Gedik, 2016). Dolayısıyla Fen Bilimleri Dersi Öğretim Programı'nda, öğrencilerin kendi öğrenmelerinden sorumlu olduğu, öğrenme sürecine aktif katılımlarının sağlanmaya çalışıldığı ve bilgiyi kendi zihinlerinde yapılandırmalarına imkân sağlayan Araştırma Sorgulamaya Dayalı Öğretim Yaklaşımı (ASDÖY) esas alınmıştır (MEB, 2013).

ASDÖY, herhangi bir konuda problemlerin veya soruların oluşturulduğu, öğrencilerin ders boyunca bunları çözmeye ve cevap bulmaya çalıştığı bir öğrenme süreci olarak tanımlanmaktadır (Wood, 2003). Bu öğrenme yaklaşımında öğrenciler, belli bir plan dâhilinde deney ve etkinlikler ile ilgili araştırma yapmaktadırlar. Öğrencilerin, yapmış oldukları araştırmalardan elde ettikleri bulguları belli bir düzende topladıkları, bu bilgileri yorumladıkları ve araç gereç kullanarak tahminlerde bulundukları görülmektedir. $\mathrm{Bu}$ öğrenme sürecinde öğrenciler elde ettiği bilgileri, önceki bilgiler ile zihinlerinde sorgulayıp yapılandırmaya gitmektedirler (Pizzolato, Fazio ve Battaglia, 2014). Bu bağlamda ASDÖY, yapılandırmacı öğrenme kuramının felsefesi ile örtüşen bir öğrenme yaklaşımı olup öğrencilerin üst düzey düşünme becerilerini geliştirmelerine ve öz düzenlemelerine yardımcı olmaktadır (Minner, Levy ve Century, 2010).

Öğrenme ortamlarında, ASDÖY'ün farklı şekillerde uygulandığı görülmektedir. Bu öğrenme yaklaşımının öğrenme ortamında uygulama türleri sırasıyla; Yapılandırılmış Sorgulama Yöntemi, Açık Uçlu Sorgulama Yöntemi ve Rehberli Araştırma Sorgulama Öğretim Yöntemi (RASÖY) şeklindedir (National Research Council [NRC], 2000). Yapılandırılmış sorgulamada, öğrenme ortamının tüm aşamaları öğretmen tarafından belirlenir ve öğrenciler bu aşamaları takip ederler. Diğer taraftan açık uçlu sorgulama yönteminde, öğrenciler öğrenme ortamını belirler ve bu ortamı öğrenme amaçları doğrultusunda dizayn edebilirler. Bu süreçte öğretmen, öğrencilerin zorlandığ 1 aşamalarda çok az yönlendirmeler yapabilir. Son yaklaşım olan Rehberli Araştırma Sorgulama Öğretim Yöntemi (RASÖY)'nde ise öğretmenin rehberliğinde öğretim gerçekleşir. Öğrenciler, öğretim sürecinde öğretim ortamını bizzat kendileri şekillendirir (Bostan-Sarıŏlan, Can ve Gedik, 2016; Çelik, Şenocak, Bayrakçeken, Taşkesenligil ve Doymuş, 2005). ASDÖY'ün öğrenme ortamındaki uygulama türleri, yapılandırmacı öğrenme kuramının temel felsefesine göre değerlendirildiğinde, RASÖY'ün yapılandırmacı öğrenme kuramının doğası ile daha uyumlu olduğu tespit edilmiştir (Minner ve diğ., 2010; Şen ve Yılmaz, 2017). Bundan dolayı bu çalışmada RASÖY kullanılmıştır.

Alanyazın incelendiğinde, RASÖY ile ilgili yapılan çalışmalarda birçok olumlu sonuca ulaşılmıştır. RASÖY temelli öğrenme ortamının, lise öğrencilerinin maddenin tanecikli konusunda kavram yanılgılarını gidermede etkili olduğu tespit edilmiştir (Barthlow, 2011). Bu konuda yapılan başka bir çalışma ise öğretmen ve öğretmen adayları ile yürütülmüştür. Çalışmaya katılanlar, RASÖY geleneksel öğretim yöntemine göre, öğrenciler arasındaki etkileşimin 
artmasını sağladığı, öğrencilerin derse katılımını en üst düzeye çıkardı̆̆ dikkat düzeylerini artırdığ 1 belirlenmiştir (Myers, Monypenny ve Trevathan, 2012). Benzer şekilde RASÖY'e dayalı öğrenme ortamının, öğrencilerin akademik başarılarını artırdığ sonucuna ulaşılmıştır (Kaundjwa, 2015; Qureshi, Vishnumolakala, Southam ve Treagust, 2016). Diğer taraftan, RASÖY ile yapılan kimya öğretiminin, öğrencilerin derse karşı tutumlarının ve öz yeterliliklerinin artmasına katkı sağladığı tespit edilmiştir (Vishnumolakala, Southam, Treagust, Mocerino ve Qureshi, 2017). Ayrıca RASÖY temelli fen öğretiminin, öğrencilerin kendi öğrenmelerini, fen bilimleri dersine karşı tutumlarını ve öğrenme ortamında öğrencilerin kendi aralarındaki etkileşimi artırdığı tespit edilmiştir (Hanson, 2004).

Alanyazında bu bulgulara benzer şekilde, RASÖY'in ilköğretim öğrencilerinin bilime karşı tutumlarını olumlu yönde geliştirdiği belirlenmiştir (Köksal ve Berberoğlu, 2014). Başka bir çalışmada ise yöntemin bilimsel süreç becerileri ve kavramsal anlayışla ilgili öğrenciler üzerinde olumlu etkileri olmasına karşın, öğrencilerin bilime yönelik tutumları üzerinde herhangi bir etkisinin olmadığı tespit edilmiştir (Şimşek ve Karapınar, 2010). RASÖY'ün, 11. sinıf öğrencilerinin elektrokimya konusuyla ilgili kavramların iyi öğrenilmesi ve kavram yanılgılarının giderilmesinde, geleneksel öğretim yöntemine göre daha etkili olduğu görülmüştür (Şen, 2015). Aynı zamanda RASÖY göre tasarlanan öğrenme ortamının öğrencilerin akademik başarılarını ve bilimsel muhakeme becerilerini olumlu yönde etkilediği tespit edilmiştir. Ayrıca öğrencilerin derse katılımlarını, fen bilimleri dersine ve öğretmene karşı tutumlarını artırdığı saptanmıştır (Gülmez-Güngörmez, 2018). Bu çalışmalara ilaveten RASÖY dayalı fen öğretiminin, yedinci sınıf öğrencilerinin bilimsel süreç becerileri üzerinde etkili olduğu tespit edilmiştir (Sağdıç, Bakırcı ve Boynukara, 2019).

\section{Araştırmanın Amacı ve Önemi}

Ulusal ve uluslararası alanyazında ASDÖY ile ilgili birçok çalışma gerçekleştirilmiştir. ASDÖY'ün farklı öğretim kademelerinde öğrenim gören öğrencilerin 21. yüzyıl becerileri üzerinde etkili olduğu (Kaya ve Yılmaz, 2016), akademik başarılarını artırdığı (Akpullukçu ve Günay, 2013), bilimsel süreç becerilerine katkı sağladığ1 (Karapınar, 2016; Keçeci ve KırbağZengin, 2016), kavramsal anlamaları artırdığı (Şen, 2015) ve fen bilimleri dersine karşı olumlu tutum geliştirdiği (Çelik ve Çavaş, 2012) sonuçlarına ulaşılmıştır. ASDÖY'ün öğrenciler üzerinde olumlu etkilerinin görülmesiyle birlikte öğretim programlarında ASDÖY'e yer verilmeye başlanmıştır. Türkiye'de 2013 yılından itibaren Fen Bilimleri Dersi Öğretim Programı, disiplinler arası bir bakış açısıyla ASDÖY'ü temel almıştır. Bu öğrenme yaklaşımının, öğrencilere 21. yüzyı1 becerileri kazandırmada etkili olduğu söylenebilir. Bu becerilerin kazandırılmasında, FeTeMM eğitiminin önemi yadsınamaz (Bybee, 2010; Çorlu, Capraro ve Capraro, 2014). Bu bilgiler ışığında ASDÖY'ün öğrenme ortamında kullanılan türlerinden biri olan RASÖY'e dayalı fen ögretiminin öğrencilerin FeTeMM tutumlarının belirlenmesi, alanyazına sağlayabileceği katkılar açısından büyük bir önem arz ettiği düşünülmektedir.

RASÖY ile ilgili yapılan çalışmalar incelendiğinde, çalışma grubunun daha çok öğretmenler, öğretmen adayları ve lise öğrencileri oldukları görülmektedir (Barthlow, 2011; Bayram, 2015; Kaundjwa, 2015; Şen, 2015). Ancak ortaokul öğrencileriyle yürütülen çalışmaların sınırlı olduğu tespit edilmiştir (Gülmez-Güngörmez, 2018). Sınırlı sayıdaki bu çalışmaların, RASÖY'ün öğrencilerin akademik başarısına (Myers ve diğ., 2012; Qureshi ve diğ., 2016), bilimsel süreç becerilerine (Köksal ve Berberoğlu, 2014; Sağdıç ve diğ., 2019) ve fen dersine karşı tutumlarına etkisi (Hanson, 2004; Köksal ve Berberoğlu, 2014) olduğu tespit edilmiştir. RASÖY'ün, yedinci sınıf öğrencilerinin FeTeMM tutumları üzerinde etkisi ile ilgili herhangi bir çalışmaya rastlanılmaması bu çalışmayı önemli kılmaktadır.

FeTeMM eğitimi ile ilgili alanyazın incelendiğinde, Türkiye'de 2010 y1lında bu alanda çalışmalar yapılmasına rağmen diğer ulusların birçoğunda 1990'dan itibaren bu çalışmaların yapıldığ görülmektedir (Bakırcı ve Karışan, 2018). Yapılan çalışmalar irdelendiğinde uluslararası alanda devletlerin birbiriyle rekabet etmesinde; nitelikli ve çağı okuyabilen bireylerin 
yetiştirilmesinde FeTeMM eğitiminin önemli bir yere sahip olduğu görülmektedir. Ayrıca bu yaklaşımın kullanılmasının bireylerin çağın koşullarına göre yetiştirilmesinde de etkili olduğu saptanmıştır (Bybee, 2010; Sanders, 2009). Türkiye'de FeTeMM eğitimi ile ilgili çalışmaların daha çok derleme şeklinde olduğu tespit edilmiştir. Bunun yanında bu konuda yapılan deneysel çalışmaların ise daha çok öğretmenler ve öğretmen adayları ile yürütüldüğü anlaşılmıştır (Bakırcı ve Karışan, 2018). Bunun yanında çok az sayıda çalışmanın Fen Bilimleri dersi kapsamında ortaokul öğrencileri ile yürütüldüğü söylenebilir. Ülkemizde FeTeMM eğitimi ile ilgili yapılan çalışmalarda elde edilen olumlu bulgular neticesinde, bu eğitim öğretim programlarında yer almaya başlamıştır. FeTeMM eğitimi ilk defa 2017 y1lında Fen Bilimleri Dersi Öğretim Programında yer almıştır (MEB, 2017). FeTeMM eğitiminin öğretim programında yer alması ile birlikte RASÖY'ün ortaokul 7. sınıf öğrencilerinin FeTeMM tutumları üzerindeki etkisinin tespit edilmesi büyük bir önem arz etmektedir.

Alanyazındaki çalışmalar dikkate alındığında; RASÖY ile ilgili çalışmaların yetersiz olduğu görülmektedir (Gülmez-Güngörmez, 2018; Köksal ve Berberoğlu, 2014). Bu çalışmaların içerisinde "Kuvvet ve Enerji" ünitesine yönelik bir çalışmaya rastlanılmaması böyle bir araştırmanın gerekliliğini ortaya koymaktadır. Ayrıca yedinci sınıf düzeyine odaklanan; "Kuvvet ve Enerji" ünitesiyle ilgili öğrencilerin FeTeMM tutumlarını tespit etmeyi amaçlayan çalışmalara rastlanılmaması da bu çalışmayı önemli kılmaktadır. Bunun yanında bu çalışmanın RASÖY'ü esas alması, bu öğretim yönteminin FeTeMM eğitiminin amaçlarıyla örtüşmesi bu çalışmayı önemli hale getirmektedir. Dolayısıyla bu araştırmanın temel problemi, "RASÖY'e dayalı fen öğretiminin ortaokul yedinci sınıf öğrencilerinin FeTeMM tutumlarına etkisi nedir?" şeklinde belirlenmiştir. Bu temel probleme dayalı olarak araştırmanının alt problemleri aşağıdaki gibidir:

1. Deney ve kontrol grubu öğrencilerinin FeTeMM Tutum Ölçeği'nde yer alan becerilerin ön test puanları arasında istatistiksel olarak anlamlı bir fark var mıdır?

2. Deney ve kontrol grubu öğrencilerinin FeTeMM Tutum Ölçeği’nde yer alan becerilerin son test puanları arasında istatistiksel olarak anlamlı bir fark var mıdır?

3. Deney ve kontrol grubunun FeTeMM Tutum Ölçeği'nde yer alan becerilerin ön ve son test puanları arasında istatistiksel olarak anlamlı bir fark var midır?

4. Deney ve kontrol grubu öğrencilerinin FeTeMM Tutum Ölçeği'nde yer alan becerilerin cinsiyet açısından ön ve son test puanları arasında istatistiksel olarak anlamlı bir fark var mıdır?

\subsection{Araştırmanın Amacı}

Bu araştırmanın amacı, RASÖY'e dayalı fen öğretiminin yedinci sınıf öğrencilerinin FenTeknoloji-Mühendislik-Matematik (FeTeMM) tutumlarına etkisini araştırmaktır.

\section{Yöntem}

\subsection{Araștırmanın Deseni}

RASÖY'ye dayalı fen öğretiminin yedinci sınıf öğrencilerinin FeTeMM tutumlarına etkisinin araştırıldığı bu çalışmada, ön test-son test eşitlenmemiş kontrol gruplu yarı deneysel desen kullanılmıştır. Bu deneysel desende kontrol ve deney grubu rastgele değil, ölçümlerle seçilmektedir. Çalışmanın yürütüldüğ̈̈ okullarda, rastgele örneklem seçimine ve grupların oluşturulmasına idari yönetimler tarafından izin verilmemesinden dolayı bu deneysel desen kullanılmıştır. Ayrıca bu desende, deney ve kontrol grubunun karşılaştırılması da yapılabilmektedir (Cook, Campbell ve Shadish, 2002; Çepni, 2011). Bunun yanı sıra çalışma grubunun olabildiğince benzer nitelikte olması ve iç geçerliliği tehdit edebilecek hata ya da etkilerin (Örneğin; zaman, denek kaybı, uygulayıcının etkisi, deneklerin seçimi ve veri toplama aracının etkisi vb.) daha rahat kontrol edilebilmesi gibi faktörler, bu yöntemin seçilmesinde etkili olan faktörlerdir (Ekiz, 2013). 


\section{2. Çalıșma Grubu}

Araştırmanın evrenini, Van ili Başkale ilçesinde bulunan bir ortaokulda 2017-2018 eğitim öğretim yılında öğrenim gören yedinci sınıf öğrencileri oluşturmaktadır. Örneklemi ise ilgili okulda bulunan iki şubede öğrenim gören toplam 85 öğrenci oluşturmaktadır. Okulda altı tane yedinci sınıf şubesi bulunmaktadır. Bu şubelere akademik başarı testi uygulanmıştır. Başarı test sonuçları birbirine yakın olan 7-A şubesi $(\mathrm{N}=45)$ deney grubu, 7-B şubesi de $(\mathrm{N}=40)$ kontrol grubu olarak belirlenmiştir. Araştırmanın hız ve pratiklik kazanması için, araştırmacı görev yaptığı okulda uygulama yapmıştır. Bu unsurlar dikkate alındığında kolay ulaşılabilir örneklem yöntemi seçilmiştir (Yıldırım ve Şimşek, 2013). Bu araştırmada gruplarda bulunan öğrencilerin cinsiyetlerine göre frekans (f) ve yüzde (\%) dağ 1 lımları ise Tablo 1'de verilmiştir.

Tablo 1. Deney ve kontrol grubundaki öğrencilerin cinsiyetlerine göre dağılımları

\begin{tabular}{lcccccc}
\hline Gruplar & & $\mathrm{K} 1 \mathrm{z}$ & \multicolumn{2}{c}{ Erkek } & \multicolumn{2}{c}{ Toplam } \\
\hline Kontrol & $\mathrm{f}$ & $\%$ & $\mathrm{f}$ & $\%$ & $\mathrm{f}$ & $\%$ \\
\hline Deney & 17 & 42.5 & 23 & 51.1 & 40 & 47.05 \\
\hline
\end{tabular}

\subsection{Veri Toplama Aracı}

$\mathrm{Bu}$ çalışmada, ortaokul yedinci sınıf öğrencilerinin FeTeMM tutumlarını belirlemek için Faber, Unfried, Wiebe, Corn, Townsend ve Collins (2013) tarafindan geliştirilen, Yıldırım ve Selvi (2015) tarafindan Türkçeye uyarlanmış olan FeTeMM Tutum Ölçeği kullanılmıştır. Bu ölçeğin, geçerlilik ve güvenirlik çalışması Yıldırım ve Selvi (2015) tarafından yapılmıştır. Bu ölçek 5'li likert şeklinde toplam 37 maddeden oluşmaktadır. FeTeMM Tutum Ölçeği dört faktör içermektedir. Bu faktörler fen (9 madde), matematik ( 8 madde), mühendislik (9 madde) ve 21. yüzyıl becerileri (11 madde) şeklindedir. Ölçeğin Cronbach Alphası $(\alpha) 0.89$ olarak bulunmuştur. Beşli likert tipindeki ölçek "Kesinlikle katıllyorum", "Katıllyorum", "Kararsızım", "Katılmıyorum" ve "Kesinlikle katılmıyorum" ş̧eklinde düzenlenmiştir. Ölçeğin puanlamas1 sırasıyla 5, 4, 3, 2 ve 1 puan şeklinde gerçekleştirilmiştir.

Araştırmacılar tarafından FeTeMM Tutum Ölçeği'nin güvenirliği yeniden hesaplanmıştır. Ölçek, araştırmacılar tarafından Van ilinde farklı dört okulda toplam 391 yedinci sınıf öğrencisine uygulanmıştır. Bu ölçek aracıllğıyla elde edilen veriler, SPSS $21.0^{\mathrm{TM}}$ programına girilerek ölçeğin güvenirlik katsayısı (Cronbach Alphası) 0.88 olarak hesaplanmıştır. Ölçekte yer alan alt disiplinlerin güvenirlik katsayıları sirasıyla; matematik $(\alpha=0.85)$, fen $(\alpha=0.86)$, mühendislik $(\alpha=0.84)$ ve 21 . yüzy1l $(\alpha=83)$ şeklinde bulunmuştur. FeTeMM Tutum Ölçeğinin geneli ve alt boyutlarının Cronbach Alpha katsayılarının 0.70'in üzerinde olduğu için ölçek güvenilir olarak kabul edilmiştir (Büyüköztürk, 2011).

\subsection{Verilerin Analizi}

FeTeMM Tutum Ölçeğinde elde edilen veriler, SPSS 21.0 $0^{\mathrm{TM}}$ paket programına aktarılmıştır. SPSS paket programına aktarılan veriler, analiz edilmeden önce bazı istatistik teknikler kullanarak verilerin dağılımı ortaya çıkarılmıştır (Kolmogorov Simirnov). Bu işlem sonucunda verilerin normal dağılım göstermediği anlaşılmıştır $(\mathrm{p}<0.05)$ Bundan dolayı verilerin analizinde parametrik olmayan testler kullanılmıştır (Büyüköztürk, 2011). Deney ve kontrol gruplarının karşılaştırmalarında parametrik olmayan testlerden Mann Whitney U-Test kullanılmıştır. Diğer taraftan grupların kendi içinde karşılaştırmalarında Wilcoxon İşaretli Sıralar Testinden yararlanılmıştır.

\subsection{Uygulama Süreci}

Uygulama, toplam dört haftada (16 ders saati) gerçekleşmiştir. Deney grubunda dersler RASÖY'e dayalı fen öğretimi ile işlenirken, kontrol grubunda ise 5E öğrenme modeline göre işlenmiştir. Deney ve kontrol grubunda dersler araştırmacı tarafından yürütülmüş̧ür. Derslerin araştırmacı tarafından yürütülmesinde; araştırmacının çalışmanın yürütüldüğü okulda öğretmen 
olarak çalışması ve çalışmanın iç geçerliliğini kontrol altına alınmak istenmesi etkili olduğu söylenebilir. Deney grubunda uygulamalar, araştırmacı tarafindan geliştirilen etkinlikler temelinde gerçekleşirken, kontrol grubunda ders kitabında yer alan etkinlikler esasında gerçekleşmiş̧ir.

\section{Bulgular}

Uygulama öncesinde deney ve kontrol grubuna uygulanan FeTeMM Tutum Ölçeği’nde yer alan farklı disiplinlere ait becerilerinin ön test puanlarına ilişkin Mann Whitney U-Testi sonuçları Tablo 2'de verilmiştir.

Tablo 2. Deney ve kontrol grubunun FeTeMM Tutum Ölçeğinde yer alan becerilerin ön test puanlarının Mann Whitney U-Testi sonuçları

\begin{tabular}{ccccccc}
\hline Ön Test & Grup & $\mathrm{N}$ & Sira Ortalaması & Sira Toplamı & $\mathrm{U}$ & $\mathrm{P}$ \\
\hline Matematik & Deney & 45 & 45.46 & 1909.50 & 631.500 & .075 \\
\cline { 2 - 7 } Becerileri & Kontrol & 40 & 36.19 & 1411.50 & & \\
\hline Fen Becerileri & Deney & 45 & 43.76 & 1663.00 & 522.00 & .068 \\
\cline { 2 - 7 } & Kontrol & 40 & 36.24 & 1263.00 & & .115 \\
\hline Mühendislik & Deney & 45 & 44.96 & 1888.50 & 652.500 & .359 \\
\cline { 2 - 7 } Becerileri & Kontrol & 40 & 36.73 & 1432.50 & & 722.000 \\
\hline 21. Yüzyıl & Deney & 45 & 43.31 & 181.00 & & .032 \\
Becerileri & Kontrol & 40 & 38.51 & 1502.00 & & \\
\hline Toplam Ölçek & Deney & 45 & 46.40 & 1949.00 & 592.00 & \\
\cline { 2 - 7 } Puanı & Kontrol & 40 & 35.18 & 1372.00 & & \\
\hline
\end{tabular}

Tablo 2 incelendiğinde, uygulama öncesinde deney ve kontrol grubunun FeTeMM Tutum Ölçeği'ndeki matematik becerilerinin ön test puanları arasında anlamlı bir farklılık olmadığ 1 görülmektedir [U=631.500, p>0.05]. Sıra ortalamaları dikkate alındığında grupların ön test puanları arasında önemli bir farklılık olmadığı görülmektedir. Benzer şekilde deney ve kontrol gruplarının fen becerilerinin ön test puanları arasında anlamlı bir fark bulunamamıştır [U=522.00, $\mathrm{p}>0.05]$.

Analiz sonuçları incelendiğinde; FeTeMM Tutum Ölçeği'ndeki mühendislik becerilerinin ön test puanları arasında anlamlı farklılık tespit edilememiştir [U=652.500, $\mathrm{p}>0.05$ ]. Ölçekte yer alan 21. yüzyıl becerilerine ilişkin ön test puanları arasında da anlamlı bir farklılık olmadığı görülmektedir [U=722.500, p>0.05]. FeTeMM Tutum Ölçeği'nin toplam puanlarının ön testleri arasında ise anlamlı bir farklılığın olduğu tespit edilmiştir [U=592.00, p<0.05]. Deney ve kontrol gruplarının FeTeMM Tutum Ölçeği'nde yer alan becerilerinin son test puanlarının karşılaştııılmasının Mann Whitney U-Testi Sonuçları Tablo 3'te sunulmuştur.

Tablo 3. Deney ve kontrol grubunun FeTeMM Tutum Ölçeğinde yer alan becerilerinin son Test puanlarının karşılaştııılmasının Mann Whitney U-Testi sonuçları

\begin{tabular}{ccccccc}
\hline Son Test & Grup & $\mathrm{N}$ & Sira Ortalamas1 & Sira Toplam1 & $\mathrm{U}$ & $\mathrm{P}$ \\
\hline Matematik & Deney & 45 & 41.65 & 1749.50 & 791.500 & .794 \\
\cline { 2 - 7 } Becerileri & Kontrol & 40 & 40.29 & 1571.50 & & \\
\hline Fen Becerileri & Deney & 45 & 46.26 & 1943.50 & 598.000 & $.036^{*}$ \\
\cline { 2 - 7 } & Kontrol & 40 & 35.33 & 1378.50 & & \\
\hline Mühendislik & Deney & 45 & 44.33 & 1862.00 & 679.00 & .185 \\
\cline { 2 - 7 } Becerileri & Kontrol & 40 & 37.41 & 1459.00 & & .392 \\
\hline 21. Yüzyıl & Deney & 45 & 43.15 & 1812.50 & 728.500 & \\
Becerileri & Kontrol & 40 & 37.41 & 1508.50 & & .087 \\
\hline Toplam Ölçek & Deney & 45 & 45.31 & 1903.00 & 638.000 & \\
\cline { 2 - 7 } Puanı & Kontrol & 40 & 36.36 & 1418.00 & & \\
\hline
\end{tabular}

Deney ve kontrol grubunun matematik becerilerinin FeTeMM Tutum Ölçeği'nin son test puanları arasında anlamlı bir farklılık bulunmamıştır [ $\mathrm{U}=791.500, \mathrm{p}>0.05]$. Benzer şekilde mühendislik becerilerinin son test puanları arasında anlamlı bir farklılık bulunmamıştır 
[U=679.000, p>0.05]. Aynı şekilde 21. yüzyıl becerileri son test puanları arasında da anlamlı bir farkl11ık tespit edilememiştir [U=728.500, $\mathrm{p}>0.05]$.

Deney ve kontrol grubunun FeTeMM tutum ölçeğindeki fen disiplinine ait son test puanları arasında anlamlılık bir farklılık tespit edilmiştir [U=598.000, $\mathrm{p}<0.05]$. Analiz sonuçları, uygulama sonrasında deney ve kontrol grubuna uygulanan FeTeMM Tutum Ölçeği'nin toplam son test puanları arasında anlamlı bir farklılık olmadığını göstermektedir [U=638.000, p>0.05]. Deney grubunun FeTeMM Tutum Ölçeği'nin ön ve son test toplam puanlarının Wilcoxon İşaretli Siralar Testi sonuçları Tablo 4'te sunulmuştur.

Tablo 4. Deney grubunun FeTeMM Tutum Ölçeğinde yer alan becerilerin ön ve son test puanlarının ikili karşılaştırılması Wilcoxon İşaretli Sıralar Testi sonuçları

\begin{tabular}{|c|c|c|c|c|c|c|c|}
\hline Alt Disiplinler & Testler & & $\mathrm{N}$ & $\begin{array}{c}\text { Sira } \\
\text { Ortalamas1 } \\
\end{array}$ & $\begin{array}{c}\text { Sira } \\
\text { Toplamı } \\
\end{array}$ & $\mathrm{Z}$ & $\mathrm{P}$ \\
\hline \multirow{4}{*}{$\begin{array}{l}\text { Matematik } \\
\text { Becerileri }\end{array}$} & \multirow{4}{*}{$\begin{array}{l}\text { Son Test } \\
\text { Ön Test }\end{array}$} & Negatif Sira & 20 & 21.30 & 426.00 & -1.12 & .259 \\
\hline & & Pozitif Sira & 17 & 16.29 & 277.00 & & \\
\hline & & Eşit & 5 & - & - & & \\
\hline & & Toplam & 42 & & & & \\
\hline \multirow{4}{*}{ Fen Becerileri } & \multirow{4}{*}{$\begin{array}{l}\text { Son Test } \\
\text { Ön Test }\end{array}$} & Negatif Sira & 15 & 13.97 & 209.50 & -1.73 & $.048^{*}$ \\
\hline & & Pozitif Sira & 20 & 21.03 & 420.50 & & \\
\hline & & Eşit & 7 & - & & & \\
\hline & & Toplam & 42 & & & & \\
\hline \multirow{4}{*}{$\begin{array}{l}\text { Mühendislik } \\
\text { Becerileri }\end{array}$} & \multirow{4}{*}{$\begin{array}{l}\text { Son Test } \\
\text { Ön Test }\end{array}$} & Negatif Sira & 13 & 14.96 & 194.00 & -2.18 & $.029^{*}$ \\
\hline & & Pozitif Sira & 23 & 20.52 & 472.00 & & \\
\hline & & Eşit & 3 & & & & \\
\hline & & Toplam & 42 & & & & \\
\hline \multirow{4}{*}{$\begin{array}{l}\text { 21. Yüzyıl } \\
\text { Becerileri }\end{array}$} & \multirow{4}{*}{$\begin{array}{l}\text { Son Test } \\
\text { Ön Test }\end{array}$} & Negatif Sira & 11 & 15.32 & 168.50 & -3.09 & $.002^{*}$ \\
\hline & & Pozitif Sira & 28 & 21.84 & 611.50 & & \\
\hline & & Eşit & 3 & & & & \\
\hline & & Toplam & 42 & & & & \\
\hline \multirow{4}{*}{$\begin{array}{c}\text { Toplam Ölçek } \\
\text { Puanı }\end{array}$} & \multirow{4}{*}{$\begin{array}{l}\text { Son Test } \\
\text { Ön Test }\end{array}$} & Negatif Sira & 14 & 15.43 & 216.00 & -2.60 & $.009^{*}$ \\
\hline & & Pozitif Sira & 26 & 23.23 & 604.00 & & \\
\hline & & Eşit & 2 & & & & \\
\hline & & Toplam & 42 & & & & \\
\hline
\end{tabular}

*Negatif siralar temeline dayalı

Tablo 4 incelendiğinde deney grubu öğrencilerinin FeTeMM Tutum Ölçeği'ndeki fen disiplinin ön ve son testinden aldıkları puanlar arasında anlamlı bir farklılık olduğu görülmektedir $[\mathrm{z}=-1.73, \mathrm{p}<0.05]$. Fark puanlarının sira ortalaması ve sira toplamları dikkate alındığında gözlenen bu farkın son test puanı lehine olduğu görülmektedir.

Deney grubu öğrencilerinin FeTeMM Tutum Ölçeği’ndeki mühendislik disiplinin ön ve son testinden aldıkları puanlar arasında anlamlı bir farklılık olduğu görülmektedir $[\mathrm{z}=-2.18$, $\mathrm{p}<.05]$. Fark puanlarının sıra ortalaması ve sıra toplamları dikkate alındığında gözlenen bu farkın son test puanı lehine olduğu görülmektedir.

Deney grubu öğrencilerinin FeTeMM Tutum Ölçeği'ndeki 21. yüzyıl becerilerinin ön ve son testinden aldıkları puanlar arasında anlamlı bir farklılık olduğu görülmektedir $[\mathrm{z}=-3.09$, $\mathrm{p}<0.05]$. Fark puanlarının sıra ortalaması ve sıra toplamları dikkate alındığında gözlenen bu farkın son test puanı lehine olduğu görülmektedir.

Deney grubu öğrencilerinin FeTeMM Tutum Ölçeği’ndeki toplam ölçek puanının ön ve son testinden aldıkları puanlar arasında anlamlı bir farklılık olduğu görülmektedir $[\mathrm{z}=-2.60$, p <0.05]. Fark puanlarının sıra ortalaması ve sıra toplamları dikkate alındığında gözlenen bu farkın son test puanı lehine olduğu görülmektedir. Kontrol grubunun FeTeMM Tutum Ölçeği'nin ön ve son test toplam puanlarının Wilcoxon İşaretli Sıralar Testi sonuçları Tablo 5' de sunulmuştur. 
Tablo 5. Kontrol grubunun FeTeMM Tutum Ölçeğinin ön ve son test puanlarının karşılaştırılması Wilcoxon İşaretli Sıralar Testi sonuçları

\begin{tabular}{|c|c|c|c|c|c|c|c|}
\hline $\begin{array}{c}\text { Alt } \\
\text { Disiplinler }\end{array}$ & Testler & & $\mathrm{N}$ & $\begin{array}{c}\text { Sira } \\
\text { Ortalamas1 }\end{array}$ & $\begin{array}{c}\text { Sira } \\
\text { Toplamı }\end{array}$ & $\mathrm{Z}$ & $\mathrm{P}$ \\
\hline \multirow{4}{*}{$\begin{array}{c}\text { Matematik } \\
\text { Becerileri }\end{array}$} & \multirow{4}{*}{$\begin{array}{l}\text { Son Test } \\
\text { Ön Test }\end{array}$} & Negatif Sira & 13 & 17.96 & 233.50 & -1.78 & .074 \\
\hline & & Pozitif Sira & 24 & 19.56 & 469.50 & & \\
\hline & & Eşit & 2 & & & & \\
\hline & & Toplam & 39 & & & & \\
\hline \multirow{4}{*}{$\begin{array}{c}\text { Fen } \\
\text { Becerileri }\end{array}$} & \multirow{4}{*}{$\begin{array}{l}\text { Son Test } \\
\text { Ön Test }\end{array}$} & Negatif Sira & 8 & 14.25 & 114.00 & -3.44 & $.001^{*}$ \\
\hline & & Pozitif Sira & 28 & 19.71 & 552.00 & & \\
\hline & & Eşit & 3 & & & & \\
\hline & & Toplam & 39 & & & & \\
\hline \multirow{4}{*}{$\begin{array}{l}\text { Mühendislik } \\
\text { Becerileri }\end{array}$} & \multirow{4}{*}{$\begin{array}{l}\text { Son Test } \\
\text { Ön Test }\end{array}$} & Negatif Sira & 9 & 20.28 & 182.50 & -2.55 & $.011^{*}$ \\
\hline & & Pozitif Sira & 28 & 18.59 & 520.50 & & \\
\hline & & Eşit & 2 & & & & \\
\hline & & Toplam & 39 & & & & \\
\hline \multirow{4}{*}{$\begin{array}{l}\text { 21. yüzyıl } \\
\text { Becerileri }\end{array}$} & \multirow{4}{*}{$\begin{array}{l}\text { Son Test } \\
\text { Ön Test }\end{array}$} & Negatif Sira & 9 & 17.56 & 158.00 & -2.92 & $.003^{*}$ \\
\hline & & Pozitif Sira & 28 & 19.46 & 545.00 & & \\
\hline & & Eşit & 2 & & & & \\
\hline & & Toplam & 39 & & & & \\
\hline \multirow{4}{*}{$\begin{array}{l}\text { Toplam } \\
\text { Ölçek Puanı }\end{array}$} & \multirow{4}{*}{$\begin{array}{l}\text { Son Test } \\
\text { Ön Test }\end{array}$} & Negatif Sira & 4 & 25.75 & & -3.61 & $.000^{*}$ \\
\hline & & Pozitif Sıra & 32 & 17.59 & & & \\
\hline & & Eşit & 3 & & & & \\
\hline & & Toplam & & & & & \\
\hline
\end{tabular}

Tablo 5 incelendiğinde kontrol grubu öğrencilerinin FeTeMM Tutum Ölçeği'ndeki fen disiplinine ait ön ve son test puanları arasında anlamlı bir farklılık olduğu bulunmuştur [z=-3.44, $\mathrm{p}<0.05]$. Fark puanlarının sıra ortalaması ve sıra toplamları dikkate alındığında gözlenen bu farkın son test lehine olduğu görülmektedir.

Kontrol grubu öğrencilerinin FeTeMM Tutum Ölçeği’ndeki mühendislik disiplinine ait ön ve son test puanları arasında anlamlı bir farklılık olduğu görülmektedir [z=-2.55, p<0.05]. Fark puanlarının sıra ortalaması ve sıra toplamları dikkate alındığında gözlenen bu farkın son test puanı lehine olduğu görülmektedir.

Kontrol grubu öğrencilerinin FeTeMM Tutum Ölçeği'ndeki 21. yüzyıl becerilerine ait ön ve son test puanları arasında anlamlı bir farklılık olduğunu görülmektedir [z=-2.92, p<0.05]. Fark puanlarının sıra ortalaması ve sıra toplamları dikkate alındığında gözlenen bu farkın son test lehine olduğu görülmektedir.

Kontrol grubu öğrencilerinin FeTeMM Tutum Ölçeği’ndeki toplam ölçek puanına ait ön ve son test puanları arasında anlamlı bir farklı1ık olduğunu görülmektedir [ $\mathrm{z}=-3.61, \mathrm{p}<0.05]$. Fark puanlarının sıra ortalaması ve sira toplamları dikkate alındığında gözlenen bu farkın son test lehine olduğu görülmektedir. Deney grubu öğrencilerinin FeTeMM Tutum Ölçeği'ndeki yer alan farklı disiplinlerin ön test ve son test puanlarının cinsiyet açısında karşılaştırılmasının Mann Whitney U-Testi Sonuçları Tablo 6'da verilmiştir.

Tablo 6. Deney grubu öğrencilerinin FeTeMM Tutum Ölçeğinde yer alan disiplinlerin ön ve son test puanlarının cinsiyete göre karşılaştırılması

\begin{tabular}{lllcccc}
\hline Alt Disiplinler & Cinsiyet & N & $\begin{array}{c}\text { Sira } \\
\text { Ortalamas1 }\end{array}$ & $\begin{array}{c}\text { Sira } \\
\text { toplam1 }\end{array}$ & U & P \\
\hline Matematik Ön Test & K1z & 25 & 24.40 & 610.00 & 140.000 & .062 \\
\cline { 2 - 7 } & Erkek & 17 & 17.24 & 293.00 & & \\
\hline Matematik Son Test & K1z & 25 & 21.98 & 549.50 & 200.500 & .757 \\
\cline { 2 - 7 } & Erkek & 17 & 20.79 & 353.50 & & \\
\hline Fen Ön Test & K1z & 25 & 20.92 & 523.00 & 198.00 & .710 \\
\cline { 2 - 7 } & Erkek & 17 & 22.35 & 380.00 & & \\
\hline
\end{tabular}




\begin{tabular}{|c|c|c|c|c|c|c|}
\hline \multirow[t]{2}{*}{ Fen Son Test } & $\mathrm{K} 1 \mathrm{z}$ & 25 & 24.84 & 621.00 & 129.00 & .062 \\
\hline & Erkek & 17 & 20.59 & 282.00 & & \\
\hline \multirow[t]{2}{*}{ Mühendislik Ön Test } & $\mathrm{K} 1 \mathrm{z}$ & 25 & 20.98 & 524.50 & 199.500 & .738 \\
\hline & Erkek & 17 & 22.26 & 378.50 & & \\
\hline \multirow[t]{2}{*}{ Mühendislik Son Test } & $\mathrm{K} 1 \mathrm{Z}$ & 25 & 22.64 & 566.00 & 184.000 & .464 \\
\hline & Erkek & 17 & 19.82 & 337.00 & & \\
\hline \multirow[t]{2}{*}{ 21. Yüzyıl Ön Test } & $\mathrm{K}_{1 \mathrm{Z}}$ & 25 & 22.22 & 555.50 & 194.500 & .644 \\
\hline & Erkek & 17 & 20.44 & 347.50 & & \\
\hline \multirow[t]{2}{*}{ 21. Yüzyıl Son Test } & $\mathrm{K} 1 \mathrm{Z}$ & 25 & 24.06 & 601.50 & 148.500 & .100 \\
\hline & Erkek & 17 & 17.74 & 301.50 & & \\
\hline \multirow{2}{*}{$\begin{array}{l}\text { Toplam Ölçek Puanı } \\
\text { Ön Test }\end{array}$} & $\mathrm{K} 1 \mathrm{Z}$ & 25 & 22.14 & 553.50 & 196.500 & .682 \\
\hline & Erkek & 17 & 20.56 & 349.50 & & \\
\hline \multirow{2}{*}{$\begin{array}{l}\text { Toplam Ölçek Puanı } \\
\text { Son Test }\end{array}$} & $\mathrm{K} 1 \mathrm{Z}$ & 25 & 23.96 & 599.00 & 151.000 & .115 \\
\hline & Erkek & 17 & 17.88 & 304.00 & & \\
\hline
\end{tabular}

Deney grubunda uygulama öncesi ve sonrası uygulanan FeTeMM Tutum Ölçeği'nin alt boyutlarının tamamının ön ve son test puanlarının cinsiyete göre karşılaştırılmasında anlamlı bir farklılığın olmadığ tespit edilmiştir [U=140.000, p>0.05; U=200.500, p>0.05; U=198.000, $\mathrm{p}>0.05]$. FeTeMM Tutum Ölçeği'ndeki toplam puanların cinsiyet açısından karşılaştırılmasında anlamlı bir farklılık bulunamamıştır [U=151.000, $\mathrm{p}>0.05]$. Kontrol grubu öğrencilerinin FeTeMM Tutum Ölçeği'nde yer alan farklı disiplinlerin ön test ve son test puanlarının cinsiyet açısından karşılaştırılmasının Mann Whitney U-Testi Sonuçları Tablo 7'de verilmiştir.

Tablo 7. Kontrol grubu öğrencilerinin FeTeMM Tutum Ölçeğinde yer alan disiplinlerin ön ve son test puanlarının cinsiyete göre karşılaştırılması

\begin{tabular}{|c|c|c|c|c|c|c|}
\hline Alt Disiplinler & Cinsiyet & $\mathrm{N}$ & $\begin{array}{c}\text { Sira } \\
\text { Ortalamasi } \\
\end{array}$ & $\begin{array}{c}\text { Sira } \\
\text { toplamı }\end{array}$ & $\mathrm{U}$ & $\mathrm{P}$ \\
\hline \multirow[t]{2}{*}{ Matematik Ön Test } & $\mathrm{K} 1 \mathrm{Z}$ & 20 & 20.60 & 412.00 & 178.000 & .739 \\
\hline & Erkek & 19 & 19.37 & 368.00 & & \\
\hline \multirow[t]{2}{*}{ Matematik Son Test } & $\mathrm{K}_{1 \mathrm{Z}}$ & 20 & 19.98 & 399.50 & 189.500 & .989 \\
\hline & Erkek & 19 & 20.03 & 380.50 & & \\
\hline \multirow[t]{2}{*}{ Fen Ön Test } & $\mathrm{K}_{1 \mathrm{Z}}$ & 20 & 22.73 & 454.50 & 135.500 & .125 \\
\hline & Erkek & 19 & 17.13 & 325.50 & & \\
\hline \multirow[t]{2}{*}{ Fen Son Test } & $\mathrm{K}_{1 \mathrm{Z}}$ & 20 & 21.40 & 428.00 & 162.000 & .430 \\
\hline & Erkek & 19 & 18.53 & 352.00 & & \\
\hline \multirow[t]{2}{*}{ Mühendislik Ön Test } & $\mathrm{K} 1 \mathrm{Z}$ & 20 & 19.05 & 381.00 & 171.000 & .593 \\
\hline & Erkek & 19 & 21.00 & 399.00 & & \\
\hline \multirow[t]{2}{*}{ Mühendislik Son Test } & $\mathrm{K} 1 \mathrm{z}$ & 20 & 19.30 & 386.00 & 176.000 & .694 \\
\hline & Erkek & 19 & 20.74 & 394.00 & & \\
\hline \multirow[t]{2}{*}{ 21. Yüzyıl Ön Test } & $\mathrm{K}_{1 \mathrm{Z}}$ & 20 & 22.58 & 451.50 & 138.500 & .147 \\
\hline & Erkek & 19 & 17.29 & 328.50 & & \\
\hline \multirow[t]{2}{*}{ 21. Yüzy1l Son Test } & $\mathrm{K}_{1 \mathrm{Z}}$ & 20 & 21.70 & 434.00 & 156.000 & .338 \\
\hline & Erkek & 19 & 18.21 & 346.00 & & \\
\hline \multirow{2}{*}{$\begin{array}{l}\text { Toplam Ölçek Puanı Ön } \\
\text { Test }\end{array}$} & $\mathrm{K} 1 \mathrm{z}$ & 20 & 21.75 & 435.00 & 155.000 & .325 \\
\hline & Erkek & 19 & 18.16 & 345.00 & & \\
\hline \multirow{2}{*}{$\begin{array}{l}\text { Toplam Ölçek Puanı Son } \\
\text { Test }\end{array}$} & $\mathrm{K} 1 \mathrm{z}$ & 20 & 20.30 & 406.00 & 184.000 & .866 \\
\hline & Erkek & 19 & 19.68 & 374.00 & & \\
\hline
\end{tabular}

Kontrol grubuna uygulama öncesi ve sonrası uygulanan FeTeMM Tutum Ölçeği’nin alt boyutlarının tamamında ön ve son test puanlarının cinsiyete göre karşılaştırılmasında anlamlı bir farklılığın olmadığ 1 tespit edilmiştir [U=178.000, $>>0.05 ; U=189.500, p>0.05 ; U=135.500$, $\mathrm{p}>0.05]$. FeTeMM Tutum Ölçeği'ndeki toplam puanların cinsiyet açısından karşılaştırılmasında anlamlı bir farklılık bulunamamıştır [U=184.000, $\mathrm{p}>0.05]$. 


\section{Tartışma, Sonuç ve Öneriler}

Deney ve kontrol gruplarının FeTeMM Tutum Ölçeği'nin ön test ve son test toplam puanları arasında anlamlı bir farklılık bulunmuştur (bkz. Tablo 2). Bu bulgu, deney grubunda uygulanan RASÖY ile kontrol grubunda uygulanan 5E öğrenme modelinin, yedinci sınıf öğrencilerinin FeTeMM tutumları üzerinde etkili olduğunu ortaya koymaktadır. Deney grubunda ortaya çıkan bu durumun, Fen Bilimleri dersinin, FeTeMM disiplinlerinden fen ve teknoloji bileşenlerini içermesinden ve etkinliklerinin fen, teknoloji ve tasarım odaklı hazırlanmasından kaynaklandığ 1 düşünülmektedir. Öğrenciler bu etkinlikleri yaparken fen-teknoloji-mühendislik ve matematik disiplinlerinde yararlandıkları söylenebilir. Bu süreçte, öğrencilerin FeTeMM eğitim yaklaşımında yer alan disiplinlerin neler olduğunu ve bunların birbirleriyle olan etkileşimlerinin nasıl olduğunu öğrendikleri anlaşılmaktadır. Bu konuda yapılan bir çalışmada, Yamak, Bulut ve Dündar (2014), FeTeMM etkinliklerinin beşinci sınıf öğrencilerinin bilimsel süreç becerileri ve fen bilimlerine karşı tutumları üzerinde etkili olduğunu saptamışlardır. Benzer şekilde Alkan-Dilbaz, Yanpar-Yelken ve Özgelen (2016), araştırma temelli öğrenmenin yedinci sınıf öğrencilerinin Fen Bilimleri dersine karşı tutumlarını araştırmışlardır. Çalışma sonucunda araştırma temelli fen öğretiminin yedinci sınıf öğrencilerinin Fen Bilimleri dersine karşı olumlu tutum geliştirdiklerini tespit etmiş̧lerdir. Alanyazında bu konuda yapılan çalışmaların sonuçlarının bu araştırmanın sonuçları ile büyük oranda örtüştüğü söylenebilir.

Deney ve kontrol grubunun FeTeMM Tutum Ölçeği'nin son test puanları kıyaslandığında, ölçeğin fen becerisi alt boyutunda anlamlı farklılık varken, ölçeğin diğer alt boyutlarında anlamlı fark bulunmamıştır. Bu farkın deney grubu lehine olduğu görülmektedir. Fen becerilerinde anlamlı farkın çıkması deney grubunda uygulanan RASÖY'ün doğasının, FeTeMM disiplinleri ile örtüşmesinden kaynaklandığına inanılmaktadır. RASÖY'ün; ögrencilerin derse katılımını artırdı $\breve{g}$, dersi daha eğlenceli hale getirdiği, öğrencilerin derse ve öğretmenlere karşı farklı bakış açısı geliştirmesine katkı sağladığı için böyle bir sonuç ortaya çıkmış olabilir (Gülmez-Güngörmez, 2018; Myers ve diğ., 2012). Deney ile kontrol grubunun FeTeMM Tutum Ölçeği'nin son test puanları arasında anlamlı farkın deney grubu lehine çıkmıştır. Deney grubunda yapılan uygulamada; öğrenci-öğrenci ve öğretmen-öğrenci etkileşiminin en üst düzeyde olması, öğrencilerin kendi öğrenme ve sorumluluklarının farkında olmaları ve üst düzey düşünme becerisi odaklı etkinliklerin yapılması bu durumun oluşmasında etkili olduğu söylenebilir (Hanson, 2004). Öğrenciler etkinlikleri yaparken bir bilim insanı gibi çalışmaları ve bu süreçte sürekli etkileşim halinde olmaları öğrencilerin derse karşı ilgili olmaları, onların FeTeMM tutumlarına olumlu katkı sağladığı düşünülmektedir. Örneğin Aydın, Saka ve Guzey (2017) tarafinda yapılan çalışmada, 4-8. sınıf öğrencilerinin FeTeMM tutumlarını araştırmışlardır. Sonuç olarak çalışmaya katılan öğrencilerin FeTeMM'e karşı olumlu tutuma sahip oldukları bulunmuştur. Yapılan başka bir çalışmada ise Kırıcı (2019), FeTeMM destekli ASDÖY'ün yedinci sınıf öğrencilerinin bilimsel yaratıcılık kabiliyetlerine ve kavramsal anlamalarına katkı sağladığını bulmuştur.

Deney ve kontrol grubu öğrencilerinin FeTeMM Tutum Ölçeği'ndeki matematik disiplinin ön ve son testinin aldıkları puanlar arasında anlamlı bir farklılık olmadığ 1 görülmektedir (bkz. Tablo 4 ve Tablo 5). Bunun yanında FeTeMM Tutum Ölçeği'nin diğer alt boyutlarının ve ölçeğin toplam puanlarının ön-son test puanları arasında son test lehine anlamlı fark bulunmuştur. $\mathrm{Bu}$ durum deney grubunda RASÖY'ün ve kontrol grubunda uygulanan 5E öğrenme modelinin yedinci sınıf öğrencilerinin FeTeMM tutumları üzerinde (matematik becerileri hariç) etkili olduğu şeklinde yorumlanabilir. Bu durum, RASÖY'ün öğrencilere farklı öğrenme firsatı sunmasının bu durumun oluşmasında etkili olduğu söylenebilir. Çünkü bu firsatlar öğrencilerin severek öğrenmelerine ve sorgulama becerilerini geliştirmelerine olanak sağlamıştır (Barthlow, 2011; Kaundjwa, 2015). Deney grubunda uygulanan öğretim yönteminin FeTeMM tutumları üzerinde etkili olmasında, ders kapsamında yapılan performans ve proje ödevlerinin etkili olduğu düşünülmektedir. Proje ve performans ödevlerinde öğrencilerin bilimsel araştırma basamaklarını takip ederek çalışmaları bu sonuç, üzerinde etkili olduğu düşünülmektedir (Değirmenci, 2011; 
Okur ve Artun, 2016). Bu konuda Acarlı ve Dervişoğlu (2018), öğretmen adayları ile bir çalışma yürütmüştür. Bu çalışmada öğretmen adayları, RASÖY'e dayalı öğretim sayesinde derste daha çok aktif olduklarını ve böylece öğrendikleri bilgilerin daha kalıcı olduğunu belirtmişlerdir. Buna ek olarak adaylar araştırma yapmayı öğrendiklerini ve özgüvenlerinin arttığını dile getirmişlerdir. Bu konuda yapılan başka bir çalışmada ise Villagonzalo (2014), RASÖY temelli öğretimin kimya dersinde lise öğrenicilerinin akademik başarılarını artırdığını belirtmiştir.

Deney ve kontrol grubunda uygulama öncesi ve sonrası uygulanan FeTeMM Tutum Ölçeği'nin alt boyutlarının tamamının ön ve son test puanlarının cinsiyete göre karşılaştırılmasında anlamlı bir farklılığın olmadığı tespit edilmiştir (bkz. Tablo 7 ve 8). Her iki grupta yapılan uygulamaların, cinsiyet değişkeninin belirleyici bir etkiye sahip olmadığı şeklinde yorumlanabilir. Dolaysıyla her iki grupta yer alan öğrencilerin benzer öğrenme ortamında yer almaları, aynı öğretmenlerden ders almaları ve benzer sosyoekonomik düzeyde olmalar ile açıklanabilir. Alanyazında cinsiyet üzerinde farklı konularda yapılan çalışmalarda değişik sonuçlara ulaşılmasına rağmen, çalışmaların büyük çoğunluğunda cinsiyet değiş̧keni üzerinde bağımsız değişkenlerin etkisinin olmadığı tespit edilmiştir (Bakırcı ve Günbatar, 2017). Örneğin Aydın ve diğ., (2017), 4.-8. sınıflarda öğrenim gören öğrencilerin FeTeMM tutumları bazı değişkenler açısından inceledikleri çalışmada, FeTeMM tutumlarında cinsiyet değişkenin etkili olmadığını saptamışlardır. Buna karşın, Yenilmez ve Balbağ (2016), fen bilimleri ve matematik lisans programında öğrenim görmekte olan öğretmen adaylarının FeTeMM'e yönelik tutumlarını araştırdığ 1 çalışmada ise, mühendislik becerileri açısında kızların erkeklere karşı daha olumlu tutum sergilediklerini tespit etmişlerdir.

Çalışmada yedinci sınıf öğrencilerinin FeTeMM'e yönelik tutumlarının olumlu olduğu belirlenmiştir. 2018 yılında güncellenen Fen Bilimleri Dersi Öğretim Programında FeTeMM yaklaşımı yer almıştır. Bu kapsamda düşünüldüğünde, RASÖY'ü temel alan fen öğretiminde FeTeMM yaklaşımına yönelik etkinliklere yer verilmesi durumunda öğretim programının amacına hizmet edeceği düşünülmektedir.

Öğretmenler derslerinde FeTeMM odaklı öğretim yaklaşımlarına yer veren öğretim modelleri kullanmaları durumunda öğrencilerin kendi yeteneklerinin farkına varmalarına yardımcı olabilirler.

\section{Kaynakça}

Acarlı D. S. ve Dervişoğlu, S. (2018). Biyoloji öğretmen adaylarının laboratuvarda rehberli sorgulamaya dayalı ögretime ilişkin görüşleri. Bilim, Eğitim, Sanat ve Teknoloji Dergisi, 2(1), 22-34.

Akpullukçu, S. ve Günay, Y. (2013). Fen ve teknoloji dersinde araştırmaya dayalı öğrenme ortamının öğrencilerin akademik başarı hatırda tutma düzeyi ve tutumlarına etkisi. Ege Eğitim Dergisi, 14(1), 67-89.

Alkan-Dilbaz, G., Yanpar-Yelken, T. ve Özgelen, S. (2016). Araştırma temelli öğrenmenin fen ve teknoloji dersine yönelik tutum ve araştırma becerileri üzerindeki etkisi. İlkögretim Online, 15(2), 708-722.

Artun, H. ve Özsevgeç, T. (2014). 5E öğrenme modeline uygun öğretim materyallerinin öğretmen adaylarının zihinsel modellerine etkisi. Amasya Üniversitesi Eğitim Fakültesi Dergisi, 3(2), 259-285.

Aydın, G., Saka, M. ve Guzey, S. (2017). 4.-8. Sınıf öğrencilerinin fen, teknoloji, mühendislik, matematik tutumlarının incelenmesi. Mersin Üniversitesi Ĕ̈itim Fakültesi Dergisi, 13(2). 787-802. 
Bakırcı, H. ve Günbatar, M. S. (2017). Öğretmen adaylarının bilgi okuryazarlık düzeyleri ile bilgi ve iletişim teknolojilerine yönelik tutumları. Ahi Evran Üniversitesi Kırşehir Eğitim Fakültesi Dergisi, 18(3), 543-563.

Bakırcı, H. ve Karışan, D. (2018). Investigating the pre-service primary school, mathematics and science teachers' STEM awareness. Journal of Education and Training Studies, 6(1), 32-42.

Barthlow, M. J. (2011). The Effectiveness of process oriented guided inquiry learning to reduce alternate conceptions in secondary chemistry (Unpublished doctoral dissertation). Liberty University, Lynchburg VA.

Bayram, Z. (2015). Öğretmen adaylarının rehberli sorgulamaya dayalı fen etkinlikleri tasarlarken karşılaştıkları zorlukların incelenmesi. Hacettepe Üniversitesi Ë̆itim Fakültesi Dergisi, 30(2), $15-29$.

Bostan-Sarığlan, A., Can, Y. ve Gedik, İ. (2016). 6. sınıf fen bilimleri ders kitabındaki etkinliklerin araştırma-sorgulamaya dayalı öğrenme yaklaşımına uygunluğunun değerlendirilmesi. Abant İzzet Baysal Üniversitesi Eğitim Fakültesi Dergisi, 16(3), 1004-1025.

Büyüköztürk, Ş. (2017). Sosyal bilimler için veri analizi el kitabı. Ankara: Pegem Akademi Yayıncilik.

Bybee, R. W. (2010). What is STEM education? Science, 329, 996.

Carlson, H. L. (1999). From practice to theory: A social constructivist approach to teacher education. Teachers and Teaching: Theory Practice, 5(2), 203-218.

Cook, T. D., Campbell, D. T. \& Shadish, W. (2002). Experimental and quasi-experimental designs for generalized causal inference. Boston: Houghton Mifflin.

Çelik, K. ve Çavaş, B. (2012). Canlılarda üreme büyüme ve gelişme ünitesinin araştırmaya dayalı öğrenme yöntemi ile işlenmesinin öğrencilerin akademik başarılarına bilimsel süreç becerilerine ve fen ve teknoloji dersine yönelik tutumlarına etkisi. Ege Eğitim Dergisi, 13(2), 50-75.

Çelik, S., Şenocak, E., Bayrakçeken, S., Taşkesenligil, Y. ve Doymuş, K. (2005). Aktif öğrenme stratejileri üzerine bir derleme çalışması. Atatürk Üniversitesi Kazım Karabekir Eğitim Fakültesi Dergisi, 11, 155-185.

Çepni, S. (2011). Araştırma ve proje çalışmalarına giriş. Trabzon: Celepler Matbaacılık.

Çorlu, M. S., Capraro, R. M. \& Capraro. M. M. (2014). Introducing STEM education: Implications for educating our teachers in the age of innovation. Education and Science, 39 (171), 74-85.

Değirmenci, Ş. (2011). Fen ve teknoloji dersinde canlılar ve enerji ilişkileri ünitesinin ögretilmesinde proje tabanlı ögrenmenin ögrenci başarısına etkisi (Yayımlanmamış doktora tezi). Selçuk Üniversitesi, Konya.

Ekiz, D. (2013). Eğitimde araştırma yöntem ve metotlarına giriş: nitel, nicel ve eleştirel kuram metodolojileri. Ankara: An1 Yayınc1l1k.

Faber, M., Unfried, A., Wiebe, E. N., Corn, J., Townsend, L. W. \& Collins, T. L. (2013). Student attitudes toward STEM: The development of upper elementary school and middle/high school student surveys. American Society for Engineering Education Annual Conference \& Exposition, 120, 6955-6976.

Gülmez-Güngörmez, H. (2018). Süreç odakl rehberli sorgulayıcı öğrenme yöntemine dâhil edilen bilimin doğası etkinliklerinin 7. sinıf ögrencilerinin kavramsal değişimlerine ve bilimsel muhakeme becerilerine etkisi (Yayımlanmamış doktora tezi). Adıyaman Üniversitesi, Adiyaman. 
Hanson, D. (2004). Process-oriented guided inquiry learning process-the missing element. What Works, What Matters, What Lasts, 4, 2-13.

Karapınar, A. (2016). Sorgulamaya dayalı ögrenme ortamının öğretmen adaylarının bilimsel süreç becerileri, sorgulama becerileri ve bilimsel düşünme yetenekleri üzerindeki etkisi (Yayımlanmamış Yüksek lisans tezi). Celal Bayar Üniversitesi, Manisa.

Kaundjwa, A. O. T. (2015). Influence of process oriented guided inquiry learning on science foundation students` achievements in stoichiometry problems at the University of Namibia, (Master of Science), Chemistry Education, University of South Africa.

Kaya, G. ve Yılmaz, S. (2016). Açık sorgulamaya dayalı öğrenmenin öğrencilerin başarısına ve bilimsel süreç becerilerinin gelişimine etkisi. Hacettepe Üniversitesi Eğitim Fakültesi Dergisi, 31(2), 300-318.

Keçeci, G. ve Kurbağ-Zengin, F. (2016). Araştırma ve sorgulamaya dayalı fen öğretiminin öğrencilerin bilimsel süreç becerilerine ve tutumlarına etkisi. International Journal of Social Science, 47, 269-287.

Kırıcı, M. G. (2019). FeTeMM destekli araştırma sorgulamaya dayalı öğrenme yaklaşımının 7. sinıf ögrencilerinin kavramsal anlama ve bilimsel yaratıcllıklart üzerine etkisi (Yayımlanmamış yüksek lisans tezi). Van Yüzüncü Yıl Üniversitesi, Van.

Köksal, E. A. ve Berberoğlu, G. (2014). The Effect of guided-inquiry instruction on $6^{\text {th }}$ grade Turkish students' achievement, science process skills and attitudes toward science. International Journal of Science Education, 36, 66-78.

Milli Eğitim Bakanlığı [MEB]. (2013). Talim ve terbiye kurulu başkanlığı ilköğretim kurumları (ilkokul ve ortaokul) fen bilimleri dersi (3, 4, 5, 6, 7 ve 8. siniflar) ögrretim programı. Ankara: Milli Eğitim Bakanlığı Yayınları.

Milli Eğitim Bakanlığı [MEB]. (2017). Öğretmen strateji belgesi. Ankara: Milli Eğitim Bakanlığ Yayınlar1.

Minner, D. D., Levy, J. A. \& Century, J. (2010). İnquiry-based science instruction what is it and does it matter? Results from a research synthesis years 1984 to 2002. Journal of Research in Science Teaching, 47(4). 474-496.

Myers, T., Monypenny, R. \& Trevathan, J. (2012). Overcoming the glassy-eyed nod: An application of process-oriented guided inquiry learning techniques in information technology. Journal of Learning Design, 5(1), 12-22.

National Research Council [NRC]. (2000). Inquiry and the national science education standards. Washington, D.C.: National Academy Press.

Okur, M. ve Artun, H. (2016). Secondary students' opinions about sound propagation. European Journal of Education Studies, 2(2), 44-61.

Pizzolato, N., Fazio, C., \& Battaglia, O. R. (2014). Open inquiry-based learning experiences: A case study in the context of energy exchange by thermal radiation. European Journal of Physics, 35(1), 1-16.

Qureshi, S., Vishnumolakala, V. R., Southam, D. C. \& Treagust, D. F. (2016). Inquiry-based chemistry education in a high-context culture: A Qatari case study. International Journal of Science and Mathematics Education, 15, 1017-1038.

Sağdıç, M., Bakırcı, H. ve Boynukara, Z. (2019). Rehberli sorgulama öğretim modeline dayalı fen öğretiminin yedinci sınıf öğrencilerinin bilimsel süreç becerileri üzerindeki etkisinin incelenmesi: Kuvvet ve Enerji Ünitesi Örneği. Yüzüncü Yll Üniversitesi Eğitim Fakültesi Dergisi, 16(1), 943-959. 
Sanders, M. (2009). STEM, STEM education, STEM mania. The Technology Teacher, 68(4), 2026.

Sarığlan, A. B., Can, Y. ve Gedik, İ. (2016). Altıncı sınıf fen bilimleri ders kitabındaki etkinliklerin araştırma-sorgulamaya dayalı öğrenme yaklaşımına uygunluğunun değerlendirilmesi. Abant İzzet Baysal Üniversitesi Ĕgitim Fakültesi Dergisi, 16(3), 1004-1025.

Şen, Ş. (2015). Süreç odakl rehberli sorgulayıcı öğrenme ortamında ögrrencilerin elektrokimya konusundaki kavramsal anlamaları ve öz düzenleyici ögrenme becerilerinin incelenmesi (Yayımlanmamış doktora tezi). Hacettepe Üniversitesi, Ankara.

Şen, Ş. ve Y1lmaz, A. (2017). Rehberli sorgulama ölçeğinin geçerlik ve güvenirlik çalışması. Yüzüncü Yıl Üniversitesi Eğitim Fakültesi Dergisi, 14(1), 1-21.

Şimşek, P. ve Karapınar, F. (2010). The effects of inquiry-based learning on elementary students' conceptual understanding of matter, scientific process skills and science attitudes. Procedia Social and Behavioral Sciences, 2, 1190-1194.

Villagonzalo, E. C. (2014). Process oriented guided inquiry learning: An effective approach in enhancing students' academic performance. DLSU Research Congress, De La Salle University, Manila, Philippines.

Vishnumolakala, V. R., Southam, D. C., Treagust, D. F., Mocerino, M. \& Qureshi, S. (2017). Students' attitudes, self-efficacy and experiences in a modified process-oriented guided inquiry learning undergraduate chemistry classroom. Chemistry Education Research and Practice, 18, 340-352.

Wood, W. B. (2003). Inquiry-based undergraduate teaching in life sciences at large research universities: A perspective on the boyer commission report. Cell Biology Education, 2(2), 112 116.

Yamak, H., Bulut, N. ve Dündar, S. (2014). 5.Sınıf öğrencilerinin bilimsel süreç becerileri ile fene karşı tutumlarına FeTeMM etkinliklerinin etkisi. Gazi Üniversitesi Eğitim Fakültesi Dergisi, 34(2), 249-265.

Yenilmez, K. ve Balbăg, Z. (2016). Fen bilgisi ve ilköğretim matematik öğretmeni adaylarının FeTeMM' e yönelik tutumları. Eğitim ve Öğretim Araştırmaları Dergisi, 5(4). 301-307.

Yıldırım, B. ve Selvi, M. (2015). Adaptation of stem attitude scale to Turkish. Turkish StudiesInternational Periodical for the Languages, Literature and History of Turkish or Turkic, 10(3), 1107-1120.

Yıldırım, A. ve Şimşek, H. (2013). Sosyal bilimlerde nitel araştırma yöntemleri. Ankara: Seçkin Yayıncilik.

\section{ETIKK ve BİLIMSEL İLKELER SORUMLULUK BEYANI}

$\mathrm{Bu}$ çalışmanın tüm hazırlanma süreçlerinde etik kurallara ve bilimsel atıf gösterme ilkelerine riayet edildiğini yazar(lar) beyan eder. Aksi bir durumun tespiti halinde Afyon Kocatepe Üniversitesi Sosyal Bilimler Dergisi'nin hiçbir sorumluluğu olmayıp, tüm sorumluluk makale yazarlarına aittir. 